\title{
Nota de la Editora
}

El libro que tienen entre sus manos es el séptimo número del Anuario de Derechos Humanos del Centro de Derechos Humanos de la Universidad de Chile. Encontrarán en sus páginas interesantes reflexiones sobre los acontecimientos más relevantes en materia de derechos humanos que tuvieron lugar el año 2010, tanto a nivel nacional como internacional. Igualmente, contiene miradas que, si bien tratan temas menos contingentes, ponen el acento en materias que permanentemente condicionan, tensionan o afectan el pleno goce de los derechos fundamentales y la democracia en Chile y en América Latina.

Un libro como el Anuario de Derechos Humanos responde, a mi juicio, a múltiples objetivos. El primero de éstos es visibilizar aquellos hechos que marcan los avances y retrocesos en temas tan fundamentales como, por ejemplo, los retos que deben enfrentar las sociedades en la transición desde regímenes dictatoriales a la democracia. El segundo, es abrir un espacio de reflexión sobre temas de derechos humanos y democracia para académicos/as y para miembros de la sociedad civil. La convergencia de estas miradas permite que la teoría se encuentre con la práctica; que situaciones y hechos aparentemente desconectados puedan ser contextualizados dentro de los márgenes y categorías propios de la filosofía política y el derecho. El tercero es invitar no sólo a quienes se han consagrado en sus campos de especialidad, sino también a quienes comienzan a hacerlo. Esta es una forma no sólo de crear oportunidades de exposición para talentos jóvenes, sino también de contribuir a los siempre necesarios recambios generacionales. El cuarto, y quizás el más relevante, es que este libro procura ser un insumo útil para quienes trabajan en favor de los derechos humanos en América Latina y en Chile, ya sea que realicen dicha tarea desde el Estado, el Poder Judicial, el Congreso, la academia o la sociedad civil organizada.

En las discusiones sobre democracia y derechos humanos no podríamos estar ajenos de la fundamental tarea de construir conocimiento para y con la sociedad. Hacer este libro desde la Universidad de Chile no sólo es un privilegio, sino también un deber. Una Universidad como la nuestra, pluralista, laica y pública, está llamada a poner a disposición de la comunidad su tradición y excelencia en el desarrollo de pensamiento social crítico.

Por supuesto, la concreción de esta ambiciosa tarea que se plasma en el Anuario de Derechos Humanos 2011 no sería posible sin la indispensable y generosa contribución de las y los autores. Son ellas y ellos quienes hacen posible que hoy presentemos este número. Mis más sinceros agradecimientos por su contribución y, claro, por la paciencia y deferencia que tuvieron con esta editora.

Agradezco también a Jennifer Metcalf, Patricia Palacios y Alia Trabucco por su esmerada tarea de traducción de los artículos escritos originalmente en inglés.

Este es mi cuarto y último número como editora del Anuario, por lo que he decidido tomarme una pequeña licencia y compartir con ustedes algunas reflexiones. Estos cuatro años liderando 
la edición y producción del Anuario han sido una experiencia que atesoraré por años. Ha sido un honor trabajar con todo el equipo del Centro de Derechos Humanos, especialmente con los profesores Cecilia Medina y José Zalaquett, quienes hace unos años decidieron confiarme la tarea de preparar el que quizás sea el trabajo más público de nuestra institución.

Espero que este libro sea de su interés y que, al igual que los anteriores, despierte inquietudes, genere debate y movilice conciencias.

Claudia Sarmiento R. Editora Anuario 2011 